\title{
RADIOCARBON DATING THE HOLOCENE IN THE GOŚCIĄŻ LAKE FLOATING VARVE CHRONOLOGY
}

\author{
IRENA HAJDAS, ${ }^{1,2}$ GEORGES BONANI, ${ }^{1}$ and TOMASZ GOSLAR ${ }^{3}$
}

\begin{abstract}
Terrestrial macrofossils selected from laminated sediment of Lake Gosciąz were dated by AMS. Thus, part of the floating varve chronology (FVC) (Goslar et al. 1993) between radiocarbon ages of $4225 \pm 45$ and $7740 \pm 85 \mathrm{BP}$ can be compared and placed on the ${ }^{14} \mathrm{C}$ calibration curve. As a result of our dating, the top of the FVC is now dated between 3120 and $3300 \mathrm{cal} \mathrm{BP}$, i.e., $3210 \pm 90 \mathrm{cal} \mathrm{BP}$.
\end{abstract}

\section{INTRODUCTION}

Terrestrial macrofossils are most suitable for radiocarbon dating lake sediments because they are free of the hard-water effect (Olsson 1986). Short-lived parts of land plants provide the best ${ }^{14} \mathrm{C}$ estimate of the time when the sediment was deposited. A danger of dating reworked macrofossils still exists and cannot be avoided entirely. However, in the case of laminated sediments, this is usually limited to such events as the development of turbidites and slumps.

In many cases, laminations are of poor quality or have disturbed sequences in the upper parts of the sediment record (Hajdas 1993). Therefore, most long varve chronologies, sometimes extending to the Late Glacial period, are either floating or show large counting uncertainties. One possibility for solving this problem is to ${ }^{14} \mathrm{C}$-date the floating varve chronology (FVC) and place it on the ${ }^{14} \mathrm{C}$ calibration curve (Hajdas et al. 1993, 1995.)

Lake Gościąż contains a sedimentary record of the last deglaciation (Goslar et al. 1993a; RalskaJasiewiczowa, Wicik and Wieckowski 1987), and most of it is well laminated. However, because of difficulty in varve counting, the uppermost $2900 \mathrm{yr}$ were counted with an uncertainty of $-200 /+500$ yr. Below this point, well-developed varves are observed, and a long varve chronology has been established (Goślar 1993; Goślar et al. 1993). To reduce the uncertainty after $2900 \mathrm{BP}$, we dated the younger part of the FVC to match it to the dendrochronologically based calibration curve. Sediment samples were selected to allow for coverage of the longest sequence of varves in this lake. Macrofossils from these samples were dated using accelerator mass spectrometry (AMS).

\section{METHODS}

Sediment samples containing ca. 100 varves (exact number given in Table 1) were treated with acid $(10 \% \mathrm{HCl})$ to remove carbonates and facilitate washing macrofossils. Gosciąż sediment contains $\mathrm{ca}$. $40-60 \%$ carbonate, so that most of the sediment was removed in this step, followed by washing through a sieve (250-mm mesh). From the remaining residue, we selected only fragments of terrestrial plants (Table 1), so that the hard-water effect, a possible uncertainty of dating, could be ruled out (Hajdas 1993).

We applied a standard cleaning procedure of a consecutive acid/base/acid soaking of organic matter at $60^{\circ} \mathrm{C}$ for $1 \mathrm{~h}$ (Hajdas 1993). Each step was followed by rinsing to neutral $\mathrm{pH}$. Combustion graphitization and sputter target preparation followed the usual procedure. The targets were measured in

\footnotetext{
${ }^{1}$ Institut für Teilchenphysik, ETH-Hönggerberg, CH-8093 Zürich, Switzerland

${ }^{2}$ EAWAG, Überlandstrasse 133, CH-8600 Dübendorf, Switzerland

${ }^{3}$ Gliwice Radiocarbon Laboratory, Institute of Physics, Silesian Technical University, Krzywoustego 2

PL-44-100 Gliwice, Poland
} 
TABLE 1. AMS-Dated ${ }^{14} \mathrm{C}$ Ages and $\delta^{13} \mathrm{C}$ Values for Macrofossils Selected from Sediment of Lake Gościąż

\begin{tabular}{llcccll}
\hline ETH-no. & Sample & $\begin{array}{c}\text { Relative } \\
\text { varve age* }\end{array}$ & $\begin{array}{c}{ }^{14} \mathrm{C} \text { age } \\
(\mathrm{yr} \text { BP })\end{array}$ & $\begin{array}{c}\delta^{13} \mathrm{C} \\
(\% 0)\end{array}$ & Material & $\begin{array}{c}\text { Ccontent } \\
\text { (mg) }\end{array}$ \\
\hline $12417,12418 \dagger$ & G(1+2)MZ & $5717 \pm 88$ & $7740 \pm 85$ & $-31.5 \pm 1.2$ & Bark, catkin scales & 1.5 \\
12423 & G7MZ & $5227 \pm 43$ & $7740 \pm 70$ & $-33.0 \pm 1.1$ & Bud, twig & 2.2 \\
12425 & G9MZ & $4645 \pm 60$ & $7075 \pm 80$ & $-27.0 \pm 1.2$ & Twig(s), bark & 1.75 \\
$12427,12428 \dagger$ & G(11+12)MZ & $2860 \pm 80$ & $5505 \pm 90$ & $-18.9 \pm 1.2$ & Catkin scales, seeds & 0.6 \\
12430 & G14MZ & $1790 \pm 45$ & $4225 \pm 70$ & $-24.0 \pm 1.3$ & Needle, leaf fragments & 2.4 \\
\hline
\end{tabular}

"In years from top of FVC; macrofossils of two samples were combined into one.

†Uncertainty corresponds to the thickness of sediment sampled for dating.

a cassette with standards (Oxalic Acid I and ANU sucrose) and blanks at the ETH/PSI AMS facility. ${ }^{14} \mathrm{C} /{ }^{12} \mathrm{C}$ and ${ }^{13} \mathrm{C} /{ }^{12} \mathrm{C}$ ratios were measured quasi-simultaneously (Bonani et al. 1987).

\section{RESULTS}

Conventional ${ }^{14} \mathrm{C}$ ages listed in Table 1 were calculated according to the procedure suggested by Stuiver and Polach (1977). Age correction for the fractionation is based on $\delta^{13} \mathrm{C}$ values (Table 1), which were measured for each graphite sample (see above). For each sample, the type of macrofossil and the amount of carbon is given. A comparison between the fitted chronology and tree-ring curve indicates that two ages (ETH-12417 and ETH-12430) are too young and fall below the calibration curve (Fig. 2). Both samples contained $>1 \mathrm{mg}$ of carbon (Table 1), and contamination is unlikely here. We tried to obtain better dating resolution, but the amount of organic material selected from sediment from other depths was not sufficient for dating.

Gościąż FVC consists of 7000 varves counted between the uppermost, poorly laminated sediment and the massive layer deposited during the YD (Goslar et al. 1993). Previously, the top of the welllaminated sediment was dated at $2900+500 /-200 \mathrm{cal} \mathrm{BP}$. Figure 1 shows ${ }^{14} \mathrm{C}$ ages of macrofossils plotted $v s$. relative varve time. Intervals between macrofossil samples contain $>500$ varves, and the whole ${ }^{14} \mathrm{C}$-dated varve chronology covers almost 4000 varve years.

We matched the Gościąz FVC with the calibration curve using the modified least-squares minimization method (Pearson 1986). We found an absolute offset of the varve age by minimizing the weighted sum of squared differences between ${ }^{14} \mathrm{C}$ ages of macrofossils and those derived from the calibration curve. The weight included uncertainties from sample sizes and AMS dating of macrofossils (Table 1) as well as uncertainties from the calibration curve. Figure 2 shows the FVC fitted to the calibration curve. The top of the FVC dates between 3120 and $3300 \mathrm{cal} \mathrm{BP}$, i.e., $3210 \pm 90 \mathrm{cal} \mathrm{BP}$.

\section{CONCLUSION}

Radiocarbon dating terrestrial macrofossils is a useful tool for the dating of lake sediments. Dating a sequence of five samples selected from the sediment deposited during a 4000-yr period allowed absolute dating of this segment. Such a strategy, called "wiggle maching" if performed with very high-resolution dating, allows more precise dating of Holocene records. In the case of the Gościąz FVC, higher-resolution ${ }^{14} \mathrm{C}$ dating could improve the fit with the ${ }^{14} \mathrm{C}$ calibration curve. 


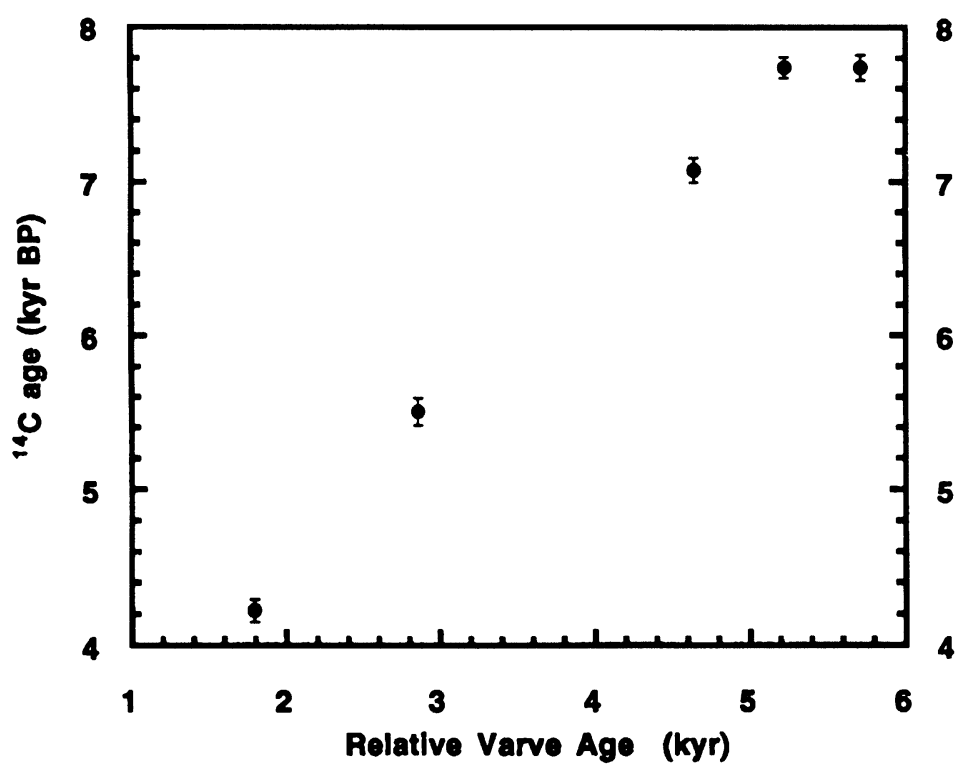

Fig. $1 .{ }^{14} \mathrm{C}$ ages of terrestrial macrofossils plotted $v s$. their relative varve age derived from varve counting

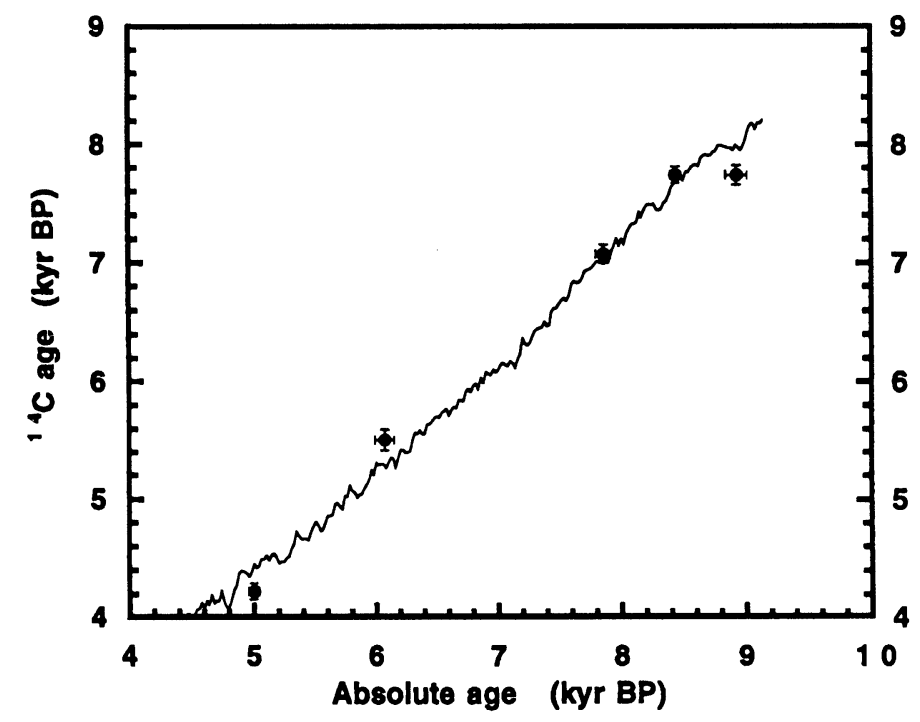

Fig. 2. The best fit of the FVC to the ${ }^{14} \mathrm{C}$ calibration curve. The top of this chronology dates to $3210 \pm 90 \mathrm{cal} \mathrm{BP}$. 


\section{REFERENCES}

Bonani, G., Beer, J., Hofmann, H., Synal, H. A., Suter, M., Wölfli, W., Pfleiderer, C., Junghans, C. and Münnich, K. O. 1987 Fractionation, precision and accuracy in ${ }^{14} \mathrm{C}$ and ${ }^{13} \mathrm{C}$ measurements. Nuclear Instruments and Methods in Physics Research B29: 87-90.

Goslar, T. 1993 Varve chronology of the Late Glacial and early Holocene parts of laminated sediments of the lake Gosciaz. Note added in proof. Polish Botanical Studies, Guidebook Series 8: 826-832 (in Polish).

Goslar, T., Kuc, T., Ralska-Jasiewiczowa, M., Rozanski, K., Arnold, M., Bard, E., van Geel, B., Szeroczynska, K., Wicik, B., Wieckowski, K. and Walanus, A. 1993 High resolution lacustrine record of the Late Glacial/ Holocene transition in Central Europe. Quaternary Science Reviews 12: 287-294.

Hajdas, I. 1993 Extension of the radiocarbon calibration curve by AMS dating of laminated sediments of Lake Soppensee and Lake Holzmaar. Ph.D. dissertation, ETH, Zürich: 147 p.

Hajdas, I., Ivy, S. D., Beer, J., Bonani, G., Imboden, D., Lotter, A. F., Sturm, M. and Suter, M. 1993 AMS radiocarbon dating and varve chronology of Lake Sop-

pensee: 6000 to $12,000{ }^{14} \mathrm{C}$ years BP. Climate Dynamics 9: 107-116.

Hajdas, I., Zolitschka, B., Ivy-Ochs, S. D., Beer, J., Bonani, G., Leroy, S. A. G., Ramrath, M., Negendank, J. F. W. and Suter, M. 1995 AMS radiocarbon dating of annually laminated sediments from Lake Holzmaar, Germany. Quaternary Science Reviews 14: 137-143.

Olsson, I. 1986 Radiometric methods. In Berglund, B., ed., Handbook of Holocene Paleoecology and Palaeohydrology. Chichester, John Wiley \& Sons: 273-312.

Pearson, G. W. 1986 Precise calendrical dating of known growth-period samples using a "curve-fitting" technique. In Stuiver, M. and Kra, R. S., eds., Proceedings of the 12th International ${ }^{14} \mathrm{C}$ Conference. Radiocarbon 28(2A): 292-299.

Ralska-Jasiewiczowa, M., Wicik, B. and Wieckowski, K. 1987 Lake Gosciąz-A site of annually laminated sediments covering 12,000 years. Bulletin of the Polish Academy of Science; Earth Science 35: 127-137.

Stuiver, M. and Polach, H. A. 1977 Discussion: Reporting of ${ }^{14} \mathrm{C}$ data. Radiocarbon 19(3): 355-363. 